DIAJAR: Jurnal Pendidikan dan Pembelajaran
https://journal.yp3a.org/index.php/DIAJAR
ISSN Media Elektronik xxxx-xxxx
Vol. 1 No. 1 (Januari 2022) 95-99
DOI: xxxxx

\title{
Analisis Nilai Sosial Dalam Novel Selamat Tinggal Karya Tere Liye
}

\author{
Cut Nyak Dhien ${ }^{1}$, Sayni Nasrah ${ }^{2}$, Emilda $^{3}$ \\ Program Studi Pendidikan Bahasa Indonesia, Fakultas Keguruan dan Ilmu Pendidikan, \\ Universitas Malikussaleh, Indonesia \\ Email: ${ }^{1}$ cutnyakdhien1999@gmail.com, ${ }^{2}$ sayni.nasrah@unimal.ac.id, ${ }^{3}$ emilda@unimal.ac.id
}

\author{
Informasi Artikel \\ Diterima : 14-12-2021 \\ Revisi : 26-12-2021 \\ Diterbitkan : 20-01-2022
}

Keywords:

Educational Values Novel Tere Liye

\begin{abstract}
This study aims to determine the social values in tere liye is novel selamat tinggal. The source of the research data is tere liye is novel.with a total of 360 pages published by PT gramedia pustaka utama, first printing in 2020. The data of this research are social values. This research method uses a descriptive method with a qualitative approach. The data analysis techniques used are to read the novel multiple time in order and the notetaking technique. The result of this research is the existence of social values in Tere liye's novel selamat tinggal. The novel Selamat Stay by Tere Liye briefly tells the social value of a child named Sintong, from a simple family on the island of Sumatra who was accepted at a famous university in Indonesia. Sintong is also a pirate bookstore keeper, and holds the title of perpetual student. He was already on the verge of studying for a period of time and went back and forth to meet with the dean to ask for an extension of time to do his final project. Until finally he managed to complete the final project and get a scholarship to continue his studies in the land of windmills, the Netherlands. Social values are able to give a positive impression to the community that under any circumstances, happiness, love, and affection will be obtained if humans can be wise in living this life.
\end{abstract}

\begin{abstract}
Abstrak
Penelitian ini bertujuan untuk mengetahui nilai sosial dalam novel Selamat Tinggal karya Tere Liye. Sumber data penelitian adalah novel Selamat Tinggal karya Tere Liye yang berjumlah 360 halaman yang diterbitkan oleh PT Gramedia Pustaka Utama, cetakan pertama pada 2020. Data penelitian ini adalah, nilai sosial. Metode penelitian ini menggunakan metode deskriptif dengan pendekatan kualitatif. Teknik analisis data yang digunakan adalah teknik baca dan teknik catat. Hasil penelitian ini adalah terdapatnya nilai sosial dalam novel Selamat Tinggal karya Tere Liye. Novel Selamat Tinggal karya Tere Liye sekilas menceritakan nilai sosial dari seorang anak yang bernama Sintong, dari keluarga sederhana di pulau Sumatera yang diterima di kampus ternama di Indonesia. Sintong juga seorang penjaga toko buku bajakan, dan mendapat gelar mahasiswa abadi. Dia sudah diambang batas masa studi dan bolak-balik bertemu dekan untuk meminta perpanjangan waktu mengerjakan tugas akhir. Hingga pada akhirnya dia berhasil menyelesaikan tugas akhir itu dan mendapatkan beasiswa melanjutkan studi ke negeri kincir angin, Belanda. Nilai sosial mampu memberikan kesan positif bagi masyarakat bahwa dalam keadaan apapun, kebahagiaan, rasa cinta, dan kasih sayang akan di dapatkan jika manusia bisa bijak dalam menjalani hidup ini.
\end{abstract}

Kata Kunci: Nilai Sosial, Novel Tere Liye

\section{PENDAHULUAN}

Kehidupan dunia atau lingkungan kita yang terjadi dan berkembang dalam kehidupan masyarakat merupakan wadah inspirasi bagi para pengarang untuk menciptakan sebuah karya sastra. 
Karya sastra hadir karena ada hal-hal yang melatarbelakanginya, yaitu kondisi sosial budaya pengarang. Oleh karena itu, karya Sastra adalah hasil imajinasi seorang pengarang yang berisi tentang gambaran isi hati, ungkapan, dan hal-hal yang dialami oleh seorang penulis berdasarkan pengalaman yang ia dapatkan dalam kehidupan sehari-hari. Menurut Setiani dan Arifin (2021:2) yang menyatakan bahwa karya sastra adalah tempat atau wadah untuk seorang pengarang menuangkan gambaran mengenai kehidupan yang di dalamnya terdapat kreasi dan imajinasi serta dukungan pengalaman kehidupan yang dituangkan. Nilai adalah kualitas suatu hal yang menjadikan hal itu disukai, diinginkan, dikejar, dihargai, berguna dan dapat membuat orang yang menghayatinya menjadi bermartabat (Sutarjo dalam Nawali, 2018:108). Nilai selalu berhubungan dengan kebaikan, kebijakan, dan keluruhan budi, serta kian menjadi sesuatu yang dihargai, dijunjung tinggi, serta dikejar seseorang sehingga ia merasakan adanya suatu kepuasan dan ia merasa menjadi manusia sebenarnya. Menurut Astuti (2015:4) nilai yang mendidik adalah nilai-nilai yang terdapat dalam masyarakat, mengajarkan tentang pendidikan kepada masyarakat. Nilai tersebut bisa diterapkan dan dipelajari melalui cerita-cerita inspiratif yang mengandung keteladanan untuk orang lain. Kisah inspiratif yang demikian bisa ditemui dalam novel-novel yang mengandung nilai sosial.

Novel merupakan suatu jenis karya sastra yang berbentuk naratif dan berkesinambungan yang ditandai oleh adanya aksi dan reaksi antar tokoh, khususnya antara antagonis dan protagonis (Semi dalam Hamzah, 2017: 2). Novel juga merupakan ungkapan fenomenal sosial dalam aspek-aspek kehidupan yang dapat digunakan sebagai sarana mengenal manusia dan zamannya. Sebagai salah satu bentuk karya sastra diharapkan dapat memunculkan nilai-nilai positif bagi para pecinta novel, sehingga mereka peka terhadap masalah-masalah yang berkaitan dengan kehidupan sosial dan mendorong untuk berperilaku baik. nilai yang terkandung dalam karya sastra berupa nilai-nilai kehidupan seperti nilai sosial,

Novel Selamat Tinggal karya Tere Liye sekilas menceritakan nilai sosial dari seorang anak yang bernama Sintong, dari keluarga sederhana di pulau Sumatera yang diterima di kampus ternama di Indonesia. Sintong juga seorang penjaga toko buku bajakan, dan mendapat gelar mahasiswa abadi. Dia sudah diambang batas masa studi dan bolak-balik bertemu dekan untuk meminta perpanjangan waktu mengerjakan tugas akhir. Hingga pada akhirnya dia berhasil menyelesaikan tugas akhir itu dan mendapatkan beasiswa melanjutkan studi ke negeri kincir angin, Belanda. Nilai sosial mampu memberikan kesan positif bagi masyarakat bahwa dalam keadaan apapun, kebahagiaan, rasa cinta, dan kasih sayang akan di dapatkan jika manusia bisa bijak dalam menjalani hidup ini.

Berdasarkan uraian di atas tersebut, penulis tertarik dan penting untuk mengkaji novel Selamat Tinggal karya Tere Liye dengan judul "Analisis Nilai sosial dalam Novel Selamat Tinggal Karya Tere Liye". Penelitian ini menarik dikaji karena nilai sosial tersebut memiliki kesan positif bagi penikmatnya sehingga mereka bisa peka dan dapat mempraktekkan perilaku baik dalam menjalani kehidupan ini

\section{METODE PENELITIAN}

Pendekatan yang digunakan dalam penelitian ini adalah kualitatif. Sugiyono (2018:10) mengemukakan bahwa penelitian kualitatif adalah penelitian yang digunakan untuk meneliti kondisi objek yang alamiah, (sebagai lawannya adalah eksperimen) dan peneliti adalah sebagai instrumen kunci, teknik pengumpulan data dilakukan secara trianggulasi (gabungan), analisis data bersifat induktif dan hasil penelitian kualitatif lebih menekankan makna daripada generalisasi. Pendekatan kualitatif digunakan untuk mendapatkan data yang mendalam, suatu data yang mengandung makna.

Data dalam penelitian ini adalah berupa kalimat yang memberikan gambaran mengenai nilai sosial yang digambarkan dalam novel Selamat Tinggal karya Tere Liye. Menurut Arikunto (2014: 172) sumber data dalam penelitian adalah subjek dari mana data dapat diperoleh. Adapun sumber data dalam penelitian ini adalah novel Selamat Tinggal dengan tebal 360 halaman. Selanjutnya Ada dua teknik pengumpulan data dalam penelitian ini, penulis menggunakan teknik baca dan teknik catat. Adapun kedua teknik tersebut dijelaskan sebagai berikut:

a) Teknik baca

Teknik baca digunakan karena dalam memperoleh data diperlukan tahap membaca, yaitu membaca disertai dengan pengamatan. Teknik baca merupakan langkah pertama yang penulis lakukan dalam penelitian ini. Penulis terlebih dahulu membaca sumber data, yaitu novel Selamat Tinggal Karya Tere Liye.

b) Teknik catat

Teknik catat juga dapat digunakan sebagai teknik dalam pengumpulan data. Mahsun (dalam Rahayu, 2013) menyatakan bahwa teknik catat adalah mencatat beberapa bentuk yang relevan bagi 
penelitian dari penggunaan bahasa secara tertulis. Setelah data berhasil dikelompokkan, langkah selanjutnya adalah menganalisis data tersebut. Oleh sebab itu, langkah kedua yang penulis lakukan adalah mencatat hal-hal yang perlu dikaji dengan memperhatikan secara mendalam.

Adapun teknik analisis data dalam penelitian ini menggunakan teknik analisis mengalir yang meliputi tiga komponen yaitu reduksi data, penyajian data, dan penarikan simpulan. Miles dan Huberman (dalam Sugiyono, 2015:377) mengemukakan bahwa kegiatan dalam menganalisis data kualitatif dilakukan cecara terus-menerus sampai tuntas, sehingga datanya sudah jenuh. Langkah-langkah teknik analisis data yaitu sebagai berikut:

1) Reduksi Data

Peneliti menyederhanakan data yang diperoleh dengan cara mengkategorisasikan datadata berdasarkan teori nilai sosial dalam novel Selamat Tinggal karya Tere Liye.

2) Penyajian Data Peneliti selanjutnya menyajikan data dalam bentuk uraian.

Data disajikan dengan cara mendeskripsikan data-data yang mengandung nilai sosial dalam novel Selamat Tinggal karya Tere Liye. dalam bentuk paragraf.

3) Penarikan Simpulan

Tahap selanjutnya yaitu penarikan simpulan. Peneliti dalam tahap ini membuat kesimpulan tentang hasil yang diperoleh dari penelitian berkenaan dengan nilai sosial dalam novel Selamat Tinggal karya Tere Liye.

\section{HASIL DAN PEMBAHASAN}

Setelah dilakukan analisis terhadap novel Selamat Tinggal karya Tere Liye, ditemukan data mengenai nilai sosial. Hasil penelitian disajikan dalam bentuk pendeskripsian untuk mendapatkan keterangan yang lebih jelas dari data yang sudah diperoleh. Hasil penelitian ini dibahas secara sistematis dengan mendeskripsikan nilai sosial yang terdapat dalam novel Selamat Tinggal karya Tere Liye.

Nilai Sosial

Kata "sosial" berarti hal-hal yang berkenaan dengan masyarakat/ kepentingan umum. Rosyadi (dalam Hamzah, 2017: 23)berpendapat bahwa Nilai sosial merupakan hikmah yang dapat diambil dari perilaku sosial. Perilaku sosial berupa sikap seseorang terhadap peristiwa yang terjadi di sekitarnya yang ada hubungannya dengan orang lain, cara berpikir,dan hubungan sosial bermasyarakat antar individu. Nilai sosial yang ada dalam karya sastra dapat dilihat cerminan kehidupan masyarakat yang diinterpretasikan.

Selanjutnya Nurachmana dkk (2020: 61) mengemukakan bahwa nilai pendidikan sosial atau kemasyarakatan sangat berkaitan dengan nilai yang lain. Nilai sosial lebih mengarah kepada bagaimana pola perilaku seseorang dalam kehidupan bermasyarakat. Nilai sosial terkait dengan masalah dasar yang sangat penting dalam hubungan antara satu dengan lainnya dalam kehidupan manusia sebagai makhluk monopluralis. Sebagai anggota masyarakat, anak didik tidak dapat melepaskan diri dari ikatan sosial. Sistem sosial yang terbentuk mengikat perilaku anak didik untuk tunduk pada norma-norma sosial,susila, dan hukum yang berlaku dalam masyarakat. Macam-macam nilai sosial menurut Sukardi (dalam Nurachmana dkk, 2020: 61). Kekeluargaan, tolong-menolong, bersimpati, dan bersahabat.

Nilai sosial merupakan nilai-nilai yang berhubungan dengan sesama. Nilai tersebut berkaitan dengan sikap sadar, hak dan kewajiban diri seseorang dan orang lain, patuh pada aturan sosial, menghargai karya dan prestasi orang lain, dan sopan santun. Manusia sebagai makhluk individu juga merupakan makhluk sosial yang memiliki kemampuan untuk berkomunikasi dengan sesame. Berikut uraian tentang nilai sosial dalam novel "Selamat Tinggal Karya Tere Liye" dan dapat kita lihat pada kutipan sebagai berikut:

"lima ribunya hitung-hitung buat ongkos angkot, bang. Kalau tujuh puluh lima ribu, nanti saya jalan kaki pulang ke rumah.” (001)

"Baiklah.” Sintong akhirnya mengangguk. Mengalah." 
Kutipan di atas menggambarkan makna kepedulian Sintong untuk mahasiswa tersebut. Memberikan buku tersebut dibeli dengan harga yang diminta mengingat mahasiswa itu supaya bisa naik angkot dan tidak perlu pulang berjalan kaki. Tak lain, maksud sintong adalah membantu mahasiswa tersebut. Menurut KBBI (2013:1772), tolong menolong berarti saling menolong dan membantu satu sama lain. Tolong menolong patut dikembangkan mengingat bahwa manusia makhluk sosial yang selalu membutuhkan interaksi dan bantuan orang lain.

"Sintong memanggil Slamet dengan panggilan "Mas", menghormati umur yang tiga puluhan. Sebaliknya Slamet, karyawan Paklik Maman di pasar Senen, juga memanggil Sintong dengan panggilan "Mas", menghormati dia sebagai keponakan juragan." (012)

Kutipan di atas menggambarkan makna sikap saling menghormati antara Sintong dan Slamet. Putri (2016: 17) mengatakan bahwa menghargi dan menghormati adalah suatu hal yang wajib yang harus melekat pada diri seseorang. Sikap menghormati tersebut ditunjukkan dengan panggilan Sintong kepada Slamet dengan sebutan "Mas" mengingat umurnya yang memang lebih tua dari Sintong. Sebaliknya Slamet juga memanggil Sintong dengan sebutan "Mas" karena menghormati Sintong sebagai keponakan dari juragan atau bos tempat dia bekerja.

"Ibu titip ini buat, Mas." Slamet mengulurkan kotak plastik itu. "Gudeg buatan Ibu. Beliau bilang. Nak Sintong telah bekerja keras beberapa hari ini, jadi dibuatkan masakan spesial.” (016)

Kutipan di atas menggambarkan makna nilai sosial menghargai kerja keras Sintong karena telah membantu beberapa hari menyiapkan di toko, dengan membuat makanan dan di titipkan untuk Sintong. Selain manghargai kerja keras Sintong, hal tersebut juga bisa digambarkan sebagai tanda ucapan terimakasih Buklik Ningrum. Menurut Syarbini (dalam Fatria 2016:7) menghargai prestasi atau kerja keras orang lain adalah sikap dan tindakan yang mendorong dirinya untuk mengsilkan sesuatu yang brguna bagi masyarakat, dan mengakui, serta mengakui keberhasilan orang lain.

"Berangkat, Bang?" anak itu betanya.

Sintong menangguk.

"Mau bareng? Pakai payung?" anak itu menunjuk payung besar yang siap dikembangkan.

"Tidak usah." Sintong menunjuk jas hujannya. Lagi pula tidak terlalu deras. "Saya duluan." Sintong melangkah di gang depan tempat kos, memperbaiki posisi ransel di pundak, melintasi gerimis." (043)

Kutipan di atas menggambarkan makna sikap kepedulian anak kos kepada Sintong, dengan mengajaknya pergi bersama menggunakan payung. Sintongpun tidak menerima ajakan tersebut dikarenakan dia juga mempunyai jas hujannya, dan berpamitan duluan melewati gang depan tempat kos. Senada dengan pendapat Saputra (dalam Erlinda, 2021) menjalin hubungan baik dapat dilakukan dengan menjunjung tinggi rasa persaudaraan, kekerabatan, dan persahabatan dalam berkomunikasi sehingga terwujudnya perdamaian. Sejatinya hidup adalah seberapa banyak kita bisa membantu orang lain.

\section{KESIMPULAN}

Simpulan yang dapat diambil dari penelitian ini adalah nilai dan makna nilai sosial yang terdapat dalam novel Selamat Tinggal karya Tere Liye yang dapat dilihat dari dialog antar tokoh dalam novel tersebut. Nilai sosial tersebut meliputi rasa tolong menolong, peduli, kekeluargaan, bersahabat dan saling menghargai. Serta makna dari nilai tersebut yang digambarkan melalui perkataan ataupun perbuatan tokoh dalam novel. 


\section{UCAPAN TERIMAKASIH}

Terima kasih atas segala pengorbanan, nasihat, dan do'a baik yang tiada hentinya kalian berikan kepadaku. Sebagai tanda bakti, hormat, dan terima kasih yang tiada terhingga kupersembahkan karya kecil ini untuk Ibunda Tiarfah dan Ayahanda Ismail. Kasih sayang kalian tidak mungkin dapat terbalas dengan selembar kertas yang bertuliskan kata ucapan terimakasih ini. Semoga ini menjadi langkah awal untuk membuat Ibu dan Ayah bahagia. Selanjutnya kepada Ibu Emilda, S.Pd., M.Pd. dan Ibu Sayni Nasrah, S.Pd., M.Pd. terima kasih sudah memberikan saran, masukan, sudah membantu, sudah diajarkan, dan mengarahkan saya sampai tugas ini selesai.

\section{REFERENCES}

[1] Arikunto, Suharsimi. 2014. Prosedur Penlitian. Jakarta: PT Rineka Cipta.

[2] Astuti, Aprilia Sri. 2015. "Nilai Edukatif dalam Novel Amelia Karya Tere Liye Tinjauan Sosiologi Sastra dan Implementasinya Sebagai Bahan Ajr Di Sma XII”. Skripsi. Universita Muhammadiyah Surakarta Fakultas Keguruan dan Ilmu Pendidikan.

[3] Erlinda, Ayu. 2021. “Analisis Nilai Pendidikan dalam Pepatah Aceh pada Masyarakat Aceh Utara”. Skripsi. Aceh Utara: Universitas Malikussaleh.

[4] Fatria, Fita. 2016. "Analisis Nilai-nilai Edukatif dalam Novel Sepatu Dahlan Karya Khrisna Pabichara”. Universitas Muslim Nusantara Al-Washliyah. Vol. 1. No. 1.

[5] Hamzah, Ilham. 2017. "Nilai Edukatif dalam Novel Mimpi Anak Negeri Karya Suyatna Pamugkas". Skripsi. Universitas Muhammadiyah Makassar Fakultas Keguruan dan Ilmu Pendidikan.

[6] Kementerian Pendidikan dan Kebudayaan Republic Indonesia. 2013. Pendidikan Pancasila Dan Kewarganegaraan . Jakarta: Politeknik Negeri Media Kreatif.

[7] Nurachmana,Alifiah. dkk. 2020. Analisis Nilai Edukatif dalam Novel Orang-orang Biasa Karya Andrea Hirata: Tinjauan Sosiologi Sastra. Universitas Palangka Raya. Vol 1. No. 1.

[8] Nawali, Ainna Khoiron. 2018. Hakikat, Nilai-Nilai Dan Strategi Pembentukan Karakter (Akhlak) Dalam Islam. UIN Sunan Kalijaga Yogyakarta.

[9] Putri, Cut Eva Syamsoeddin. 2016. "Analisis Pesan Moral dalam Cerita Rakyat Di Kecamatan Kuta Malaka”. Skripsi. Banda Aceh: Universitas Syiah Kuala.

[10] Rahayu, Actri Putri. 2013. "Analisis Makna Fukugoudoushi Au dalam Kalimat Bahasa Jepang”. Skripsi (Internet),(http://repository.upi.edu/8748/). diakses tanggal $25 \quad$ Agustus 2021.

[11] Setiani, Febri dan Zainal Arifin. 2021. "Nilai Edukatif Tokoh Burlian dalam Novel Si Anak Spesial Karya Tere Liye: Tinjauan Sosiologi Sastra Sebagai Bahan Ajar Cerita Inspiratif”. Jurnal Pendidikan, Bahasa, Sastra, Seni, dan Budaya.

[12] Sugiyono. 2018. Metode Penelitian Kualitatif. Bandung: Alfabeta.

[13] Sugiyono. 2015. Metode Penelitian Pendidikan Pendekatan Kuantitatif, Kualitatif, dan R\&D. Bandung: Alfabeta. 